\title{
A Study of State of Food Retail Supply Chain in Saudi Arabia: A Conceptual Framework
}

\author{
Salah Mahmoud Abunar ${ }^{1}$, Mahmood Ali ${ }^{1}$, Mohammed Fazelrabbi ${ }^{1} \&$ Hosam Ismail ${ }^{2}$ \\ ${ }^{1}$ College of Business Administration, University of Business \& Technology, Jeddah, Saudi Arabia \\ ${ }^{2}$ University of Liverpool, Liverpool, UK \\ Correspondence: Mahmood Ali, College of Business Administration, University of Business \& Technology, \\ Jeddah, Saudi Arabia. Tel: 966-2-215-9161. E-mail: m.ali@ubt.edu.sa
}

Received: February 15, 2015

Accepted: May 17, 2016

Online Published: June 14, 2016

doi:10.5539/emr.v5n2p1

URL: http://dx.doi.org/10.5539/emr.v5n2p1

\begin{abstract}
Supply Chain Management has been playing a key role in food retail business in the developed countries by providing various segments of customers with quality products in a highly-efficient manner. The Kingdom of Saudi Arabia (KSA) is following the lead of the developed countries through a rapid growth trend in super and hypermarkets. However, the role of supply chain management in proposing products which meet customers' needs has not, up to now, been definitely-set, well-established or thoroughly investigated because of a lack of readily-made-available data. There is an obvious need for an appropriate framework for KSA's food retail sector for the purpose of studying the roles and impacts of the various divisions of the supply-chain process. This paper describes a conceptual framework that researchers can utilize to further study the current conditions of supply-chain and its impacts on the food retail sector in Saudi Arabia.
\end{abstract}

Keywords: retail sector, supply chain management, supermarkets, Kingdom of Saudi Arabia

\section{Introduction}

The Kingdom of Saudi Arabia (KSA) is a major emerging economy in the Middle East. A good part is owed to its Government's drive in supporting the economy of the Kingdom, coupled with boosting the spending power of the Saudi citizens. This has significantly contributed towards a growth in the dynamic food retailing sector, including the grocery industry in both: super and hypermarkets. However, out of the developing countries, the Saudi retail sector ranked $16^{\text {th }}$ in retail expansion according to Shabat and Moreiarti (2012). Moreover, Swartz (1997) described the Middle East, inclusive of KSA, as a "potential franchising hotspot" pertaining to an intense competition amongst its businesses to attract foreign investors. Whilst, Young (2001) concluded that there is a long-term potential in the Middle East market as the region has been adapting to new circumstances, and henceforth, is likely feasible and more tolerant for adjustments. For instance, the Saudi household unit is enormous when compared with that of a typical Western family. Hence, Saudis have a tendency to buy large quantities of consumer products and food stuffs (Culpan, 1985). Of course, such expenditure helped the super and hypermarkets expand and flourish all throughout the Kingdom, increasingly contributing to its overall economic activity.

In addition, the Saudi government's plan to inject SR 100 billion during the next 5 years in support of its economy has also definitely and positively stirred up its markets. In return, this has contributed to a current $40 \%$ increase in consumer shopping at major retailers, in contrast to Al Kathery's (2011) anticipated $60 \%$ growth (Al-Rajhi Capital, 2010).

The area of information sharing in the retail industry and the advantages of collaborative supply-chain activity between suppliers and retailers has been a subject of several studies (Inc, 1993; Cachon \& M, 1997; Clark \& Hammond, 1997). These studies have highlighted the importance of implementing these concepts through the introduction of new technology, collaboration and information sharing with upstream and downstream partners. Cachon and Fisher (1997) suggest that sharing information and real time demand are important factors for improving supply chain performance. Whilst, Lee and Moinzadeh (1986) found that sharing information in the grocery sector could lead to 23 percent reduction in cost. 
The review of the literature and the current state of the Saudi food retailing sector, evident in a lack of research in this area, suggest a huge gap in the literature covering the supply chain in Saudi food retailing sector. The statistical data, be it from governmental or private associations, is very limited, and where it is available, it is ambiguous and loosely covers the entire retailing sector. The structure and nature of the relationship between the KSA's supermarket and its suppliers, the degree of supply chain integration, as well as the conflicts within the sector have not yet been discussed in the literature of supply chain industry. Among the few studies in this area, Al-Sudairy and Tang (2000) identify the extent of information technology used in the supermarket chains in Saudi Arabia. While, in a recent research, Qureshi, Ansari and Sajjad (2013), investigate the contemporary issues faced by human resources management in the KSA's retail sector. In research, it is concluded that due to the active growth in the retail sector, human resources management has become eminent in relation to other managerial initiatives and plays a critical role in the retail industry. Mahfooz (2014) focused on the relationship between service quality and customer satisfaction in hypermarkets in Saudi Arabia. It's also worth noting that, in this study, data was collected using questionnaires carefully composed based upon "convenience sampling" techniques. It does not, however, cover the particular issues with the food supply chain in the country.

The work described in this paper evaluates the current state of supply chain retail industry and examines the nature of the collaboration between the supply-chain partners involved in the trading process in the Kingdom of Saudi Arabia. This paper addresses the next stage in improving the understanding the state of the retail supply chain by proposing a conceptual framework which encourages further studying, evaluating and then offering strategies to enhance the collaboration and integration between supply chain partners in KSA. Therefore, this study is structured as follows: the first part review the literature on the supermarket industry in developing countries and KSA supermarket context. The second part presents the conceptual framework. The third part highlights the research questions which this research is seeking answers, followed by a conclusion and the future work.

\section{The Supermarket Industry in Developing Countries}

Remarkably but not surprisingly, the natures of developing countries appear to vary in many ways from those of developed countries in terms of economic stability, cultural considerations, industrial resources and technological reliability (Goldman, 1974). Consequently, developing countries, particularly those in Latin America, Asia, Central Europe, Eastern Europe, and parts of the African continent, as had been foreseen, lagged behind in introducing retail services into their markets, that which has notably affected the subsequent development of these services. In fact, food retailing in developing countries was traditionally limited to supplying customers with basic-life provisions such as sugar, eggs, oil and rice. Similarly, meats and poultry were usually sold in special shops.

Literature suggests that the growth of the number of supermarkets from 1950 to 1980 was not only very slow, but had also concentrated in big cities, as it was particularly there where customers of higher-incomes settled (Holton, 1953; Galbraith \& Holton, 1965; Goldman, 1974; Findlay et al., 1990). Goldman (1974) argued that the slow growth in developing countries occurred for a number of reasons. One reason was that of the richer classes' lack of interesting actually buying retail products, a second was the high cost of transportation to and from supermarkets, and a third was that the prices of goods were higher than it were in traditional groceries and food corner-shops. It's worth noting, however, that buying from a supermarket was still a new concept at the time. Therefore, getting customers to break their traditional and social habits or contradict their social norms and cultural teachings, especially in their everyday practices, of course, entailed devising effective marketing plans. In response, supermarkets had to reduce their selling prices so as to attract their intended consumers. The growth which then followed, as Reardon, Henson and Berdegue (2007) argue, was the result of the change in shopping habits of the female shopper and that in the social attitude of high-income earners. This contributed to the largest increase in the number of supermarkets in the developing countries in the 1990's.

According to Reardon et al. (2007), the transformation took place due to different reasons. One is the fact that consumers were increasingly becoming able to afford the equipment, such as refrigerators to store and sustain foods for longer times. In addition, improvement in the transport infrastructure allowed for easier and more efficient means for transporting goods to and from supermarkets by their suppliers/manufacturers (Reardon et al., 2003a; Wrigley, 2000). In the US, for instance, the supermarket share of the retailing sector ranged between 75-80 percent in 2005. While, in some developing countries such as in most of South America, East Asia, Northern Europe, Eastern Europe, Baltic, the approximate value of supermarket share of retailing revenues increased from 10-20 percent in 1990 to $50-60$ percent in the $2000 \mathrm{~s}$. 


\section{The Saudi Arabian Supermarket Context}

The first supermarket in the KSA was established in the Eastern region in Al-Dahran in 1974. Originating in 1974, it was run by British management and was later owned by AL-Souk Company Limited. Since then, the retail market in Saudi Arabia has undergone rapid transformation due to rationalization and modernization combined with huge expansion (Rossides, 1994). The retail food industry has grown vastly during the last ten years in KSA. These outlets are most popular among the Saudi consumers and have resulted in a rapid increase in the number of supermarkets in the last ten years (Leonidou, 1991).

Previously, Rossides (1994) observed, the corner shop was the dominant form in the Saudi retail market. There were very few modern self-service stores or supermarkets offering wide ranges of goods to customers. Alawi (1986) stated that the emergence of supermarkets in KSA was motivated by various factors. One, for instance, is the Government's incentives to encourage trades men to practice and apply the newly implemented and desired ways to business. Another factor lies in the general rise in customers' incomes, the readiness of the traders, and the availability of start-up funds offered by the government. Supermarkets initially started in the Kingdom's bigger cities such as Riyadh and Jeddah. The sizes of stores at the time were limited and managed to sell a relatively small number of groceries' items. By the 1980s, there was a major change in how supermarkets did their business. Simply put, the markets adopted high pricing strategy while targeting affluent customers to increase profit margins. This strategy was very successful at the beginning in attracting middle and high-income earners because of the features of the stores being generally clean, organized and air-conditioned. However, later supermarkets reviewed their pricing strategy to target more customers to compete against other stores. Let alone, customers in the region started expecting much more than quality and low prices, and customer loyalty was becoming even harder to retain (Alshaya, 2001). The supermarkets responded by enhancing their services through opening new sections inside their stores to provide a variety of products to their customers (Alawi, 1986; Al-Sudairy \& Tang, 2000). Supermarkets who had previously sold 12,000 items increased sales up to 50,000 items within a short time. At the present, there are 21 large supermarket chains in KSA. The size of the supermarket depends on the number of chains or the size of the store (Al-Sudairy et al., 2000).

\section{Previous Studies on Measuring Supply Chain Collaboration}

Literature review suggests limited research in the area of retail-supply-chain. Lowson (2001) analyse the operational strategies of retailers in the both of USA and Europe, and conclude that retail supply chain managers employ a broad array of strategies to overcome the operational challenges. Adopting those strategies, Morrison and van Assendelft (2002) find that top-performing retailers held one-third less inventory when compared with average ones. In addition, top retailers hold more than the double revenue growth and one-third higher operating income margins than average retailers. In other studies, researchers focus on the micro perspectives. For instance, Hines et al. (2006) study a single product's link between suppliers and retailers, Fernie, Pfab and Marchant's (2000) studies on grocery supply chain in Spain, while Mejias and Prado's (2002) studies on that of the UK's retail supply chain. Mukhopandhyay and Setaputra (2006) suggest that the value of outsourcing on retailers cost reverse logistics activities. Kent and Mentzer (2003) developed a concept of relationship strength using retailers as part of the sample.

Al-Falah et al. (2003) find a lack of Supply Chain Management (SCM) awareness in Saudi manufacturers and a need to integrate the supply chain with the suppliers. Rather, it is observed that Saudi manufacturers view supply chain management as part of a traditional inventory management system. Simatupang and Sridharan (2005) propose an instrument to measure the extent of collaboration in a supply chain, based upon suppliers' and retailers' use of information sharing, decision synchronization, and incentive alignment. Ramadas and Spekman (2000) studied the collaborative practices of high performers in innovative product supply chains and high practice performance in functional-product supply chain.

\section{A Conceptual Framework}

Indeed, literature on the matter suggests a lack of research in the area of retail food supply chain in the KSA. Therefore, we present here a comprehensive conceptual framework for analyzing the state of food retail supply chain in the Saudi Arabian supermarket sector. In order to have a comprehensive understanding of the current state of the retail food supply chain, this study proposes an analysis of all the factors involved in the supply chain using the qualitative and quantitative methodology as shown in Figure 1. 


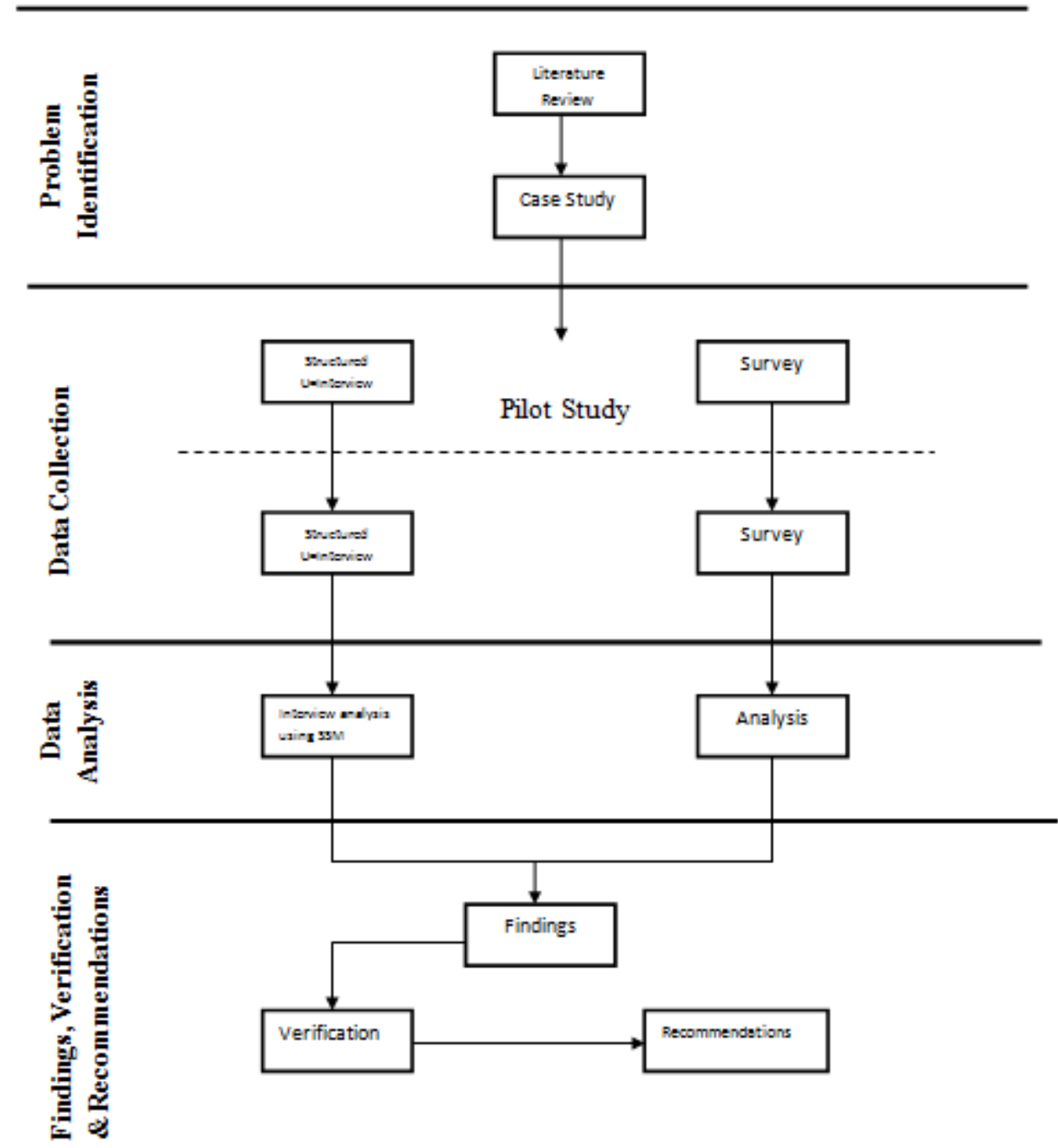

Figure 1. Research framework

The general methodology for a critical assessment of framework consists of the following steps:

\subsection{Literature Review}

A comprehensive literature review will be performed gain the understanding of the area of supply chain. The literature review will cover supply chain management, its benefits and challenges, and the collaborative role of IT in the supply chain activity. Next, the supermarket industry in developed countries such as the USA and the UK's will be examined. It will be followed by a review of the supermarket industry in the KSA to offer a better understanding of the Saudi market, underlying cultural issues, economic factors, IT usage and human resources. The focus of the literature review will be the articles, research journals, conference proceeding papers and news' articles. To gain a comprehensive understanding of the matter, the review will not be limited to one specific subject, but will rather cover the topic in its broader sense.

\subsection{Case Study}

Next, a qualitative case-study approach shall be adopted and two case studies are to be conducted to better answer key "why" and "how" questions. Yin (2003) suggests that such an approach is an ideal method, especially when a "how" and "why" question is being asked about a set of events over which the investigator has little or no control over. As a matter of fact, the "how" questions are usually associated with describing relationships, while the "why" questions tend to explain the reasons why those relationships exist (Yin, 2003). Two organizations, one from the UK and another from the KSA, will be selected for the case-studies. This will 
allow for an in-depth analysis of the cases studied and a better understanding of the behavior of the retail sector, comparing the SCM practices between the UK and the KSA.

\subsection{Consumers Survey}

Once the two markets are compared, in the next phase, this research shall conduct a quantitative consumer survey to illustrate how consumers' shopping preference and satisfaction are influenced by the collaboration between suppliers and retailers. In addition, the way the nature of the relationship between suppliers and retailers affects the consumer's shopping decision and level of satisfaction at the services' level in the Saudi supermarket shall be discussed. The sampled population in the survey shall consist of a wide and diverse variety of Saudi consumers in society.

\subsection{Structured Interviews}

The structured interviews will be carried out with key suppliers or retailers in the Saudi organization. Based on the fact that the relationship between retailers and their supplier have a profound impact on the consumers, the primary purpose of the interviews is to extract information on the procedures and the processes adopted in their daily operational activities. Besides acquiring more information about the retail supply chain in the KSA, which suffers from a lack in literature, the structured interview could assist in identifying internal difficulties faced by Saudi supermarkets from different perspectives. This could include gaining further insight into the technology used to test the quality of the products inside the organizations, the mechanisms employed to identify expired goods, and the stages of the supply chain process from order placement up to successful delivery. Therefore, a detailed investigation shall be carried out encompassing the major actors, retailers and suppliers.

\subsection{Data Analysis and Proposed Model}

In the next phase of this research, the collected data including data analysis tools and Soft System Methodology shall be analyzed. The derived findings will be used to propose a model to examine the state of retail supply chain and propose recommendations to enhance the collaboration between the suppliers and retailers for a more effective and integrated supply chain.

\subsection{Verification of a Model}

The last phase of the research involves model verification. Model verification is an essential part of any model development since it ensures and validates the basic construction and performance of the model. According to Sargent (2011), the developers and users of these models, the decision makers using this information obtained from the results of these models, and the individuals affected by decisions based on such models are rightly concerned with whether a model and its results are "correct". Therefore, the model verification process is intended to ensure that the model does what it is intended to do. Usually, in model verification purposes, there are acceptable ranges and a model is considered "valid" if the results it produces are within these ranges (Ali, 2013).

Therefore, to verify the validity and practicality of the recommendations, this research will present its findings and some useful recommendations of professionals working in the supply chain of major retail supermarkets in the KSA to seek their opinions on the various matters in discussion. In addition, the value of these findings and its practical application shall also be verified.

\section{Development of Research Framework}

The proposed framework discussed and shown in Figure 1 has yet to be developed. Once the data is collected and analysed, it can assist in gaining an insight into the current condition of the supply-chain in the KSA, and thereafter, specific \& required changes can be recommended. The proposed framework should assist in identifying and evaluating the following:

- To identify the level of information sharing between the retailer and supplier.

- To discover how supermarkets deal with the quality of the products once they receive them from suppliers and if they use certain checking procedures.

- To find out how the retailers check the stock, and what is the behaviour of inventory management in Saudi supermarkets.

- To identify how they are processing the orders and the procedures suppliers follow in order to get orders from supermarkets.

- To evaluate the effectiveness of communication in enhancing the supply chain performance.

- To evaluate the impact of suppliers and retailers relationship on the services provided to the customers. 
Furthermore, different strategies can be analyzed and implemented to ensure a reliable and efficient supply chain system.

\section{Conclusion and Future Prospects}

This paper proposes a conceptual framework which opens a way for a precise and factual evaluation of the state of the retail food supply chain in the Kingdom of Saudi Arabia. Responding to an evident lack of research in this area, this study aims at filling the gap in knowledge by evaluating the current state of the retail supply chain in the Kingdom and the circumstances which bound it. The retail supermarket sector of the KSA is fortunately still at its outset. Even though major supermarkets, local and foreign, are heavily investing in setting up new distinguished businesses, surprisingly, however, they are hardly applying the appropriate strategies and schemes underlying the supply chain system. This, in turn, causes operational difficulties, which inevitably lead to financial losses and a significant drop in customers' loyalty. Therefore, findings and recommendations drawn from this framework could enable the practitioners and researchers to gain further insight into the condition of the supply chain industry in Saudi Arabia, and its effect on the food-retail process in particular. More importantly, the viewpoint of incorporating "proper" strategies into their operations could evidently make organizations in the supply chain system more efficient and responsive, especially to external environments.

\section{References}

Al Kathery, S. M. (2011). Saudi retailing Aleqtisadih. Riyadh, Saudi Company for Publication and Distribution.

Alawi, H. M. A. (1986). Saudi Arabic: Making sense of self-service. International Marketing Review, 3(1), 21-23. http://dx.doi.org/10.1108/eb008296

Ali, M. (2013). A decision support for ERP implementation in Small and Medium enterprises (PhD Thesis).

Al-Falah, K., Zairi, M., \& Ahmed, A. M. (2003). The role of Supply Chain management in world class manufacturing. International journal of physical distribution and Logistics management, 33(5), 396-407. http://dx.doi.org/10.1108/09600030310481979

Al-Rajhi Capital. (2010). Saudi Retail Sector Report.

Al-Shaya. (2001). The future shape and characteristics of the region's new retail landscape, Exploring the middle east as a region of retail excellence (pp. 30-31). Retail week world class retailing seminar proceeding.

Al-Sudairy, M. A., \& Tang, N. K. H. (2000). Information technology in Saudi Arabia's supermarket chains. International Journal of Retail \& Distribution Management, 28(8), 341-356. http://dx.doi.org/10.1108/09590550010337292

Cachon, G., \& F. M. (1997). Campbell Soup's continuous product replenishment program: Evaluation and enhanced decision rules. Prod Oper. Management, 6, 266-276. http://dx.doi.org/10.1111/j.1937-5956.1997.tb00430.x

Clark, T., \& Hammond, J. (1997). Reengineering channel reordering processes to improve total supply chain performance. Prod. Oper. Management, 6, 248-265. http://dx.doi.org/10.1111/j.1937-5956.1997.tb00429.x

Culpan, R. (1985). The Saudi Arabian marketing environment: A critical appraisal. Journal of International Marketing and Market Research, 10(3), 129-141.

Fernie, J., Pfab, F., \& Marchant, C. (2000). Retail grocery logistics in the UK. International Journal of Logistics Management, 11(2), 83-92. http://dx.doi.org/10.1108/09574090010806182

Findlay, A., Paddison, R., \& Dawson, J. (1990). Retailing Environments in Developing Countries. London, Routledge. http://dx.doi.org/10.4324/9780203976715

Galbraith, J., \& Holton, R. (1965). Marketing Efficiency in Puerto Rico. Harvard University Press, Cambridge, MA. http://dx.doi.org/10.4159/harvard.9780674491595

Hines, P., Francis, M., \& Bailey, K. (2005). Quality-based pricing: A catalyst for collaboration and sustainable change in the agrifood industry? International Journal of Logistic Management, 17(2), 240-259. http://dx.doi.org/10.1108/09574090610689970

Holton, R. (1953). Marketing structure and economic development. Quarterly Journal of Economics, 67(3), 344-361. http://dx.doi.org/10.2307/1881693

Inc, K. S. A. (1993). Efficient Consumer Response: Enhancing Consumer Value in the Grocery Industry. Food Marketing Institute, Washington 
Kent, J. L., \& Mentzer, J. T. (2003). The effect of investment in inter-organizational information technology in a retail supply chain. Journal of Business Logistics, 24(2), 155-175. http://dx.doi.org/10.1002/j.2158-1592.2003.tb00050.x

Lee, H., \& Moinzadeh, K. (1986). Batch size and stocking levels in multi-echelon repairable systems. Management Sci, 32, 1567-1581. http://dx.doi.org/10.1287/mnsc.32.12.1567

Leonidou, L. (1991). Marketing in the Gulf states. Management Decision, 29(8), 38-45. http://dx.doi.org/10.1108/eum0000000000085

Lowson, R. H. (2001). Retail operational strategies in complex supply chains. International Journal of Logistics Management, 12(1), 97-111. http://dx.doi.org/10.1108/09574090110806253

Mahfooz, Y. (2014). The relation between Service Quality and Customer Satisfaction in Hypermarkets in Saudi Arabia. International Journal of Marketing Studies, 6(4), 10-17. http://dx.doi.org/10.5539/ijms.v6n4p10

Mejias-Sacaluga, \& Prado-Prado, J. C. (2000). The integrated logistics management in the grocery supply chain. $\begin{array}{lllll}\text { International Journal of Logistic } & \text { Management, } & \text { 13(2), } & \text { 26-77. }\end{array}$ http://dx.doi.org/10.1108/09574090210806432

Morrison, G. P., \& van Assendelft. (2006). Charting a new course: The retail merchandising supply network. Supply Chain Management Review, 10(8), 54-60.

Qureshi, M. O., Ansari, Z. A., \& Sajjad, S. R. (2013). A study of the contemporary issues of human resources management in the retail sector of Saudi Arabia. Interdisciplinary Journal for Contemptoray Research in Business, 4(9), 1205-1216.

Ramadas, K., \& Spekman, R. E. (2000). Chain and Shackles? Understanding what drives supply chain performance. Interfaces, 30(4), 3-21. http://dx.doi.org/10.1287/inte.30.4.3.11644

Reardon, T. C., Timmer, B. C., \& Berdegue, J. (2003a). The rise of supermarkets in Africa, Asia, and Latin America. American Journal of Agricultural Economics, 85, 1140-1146. http://dx.doi.org/10.1111/j.0092-5853.2003.00520.x

Reardon, T., Henson, S., \& Berdegue, J. (2007). Proactive fast-tracking' diffusion of supermarkets in developing countries: Implications for market institutions and trade. Journal of Economic Geography, 7(4P), 399-431. http://dx.doi.org/10.1093/jeg/lbm007

Rossides, N. (1994). The business climate in post-Gulfwar Saudi Arabia. Management research Today, 22(5), $15-22$.

Sargent, R. G. (2011). Verification and validation of simulations model. Proceeding of the 2011 Winter Simulation Conference, New York, USA. http://dx.doi.org/10.1109/WSC.2011.6147750

Shabat, H. B., \& Moriarty, M. (2012). Global Retail Expansion: Keeps On Moving. ATKearney.

Simatupang, T. M., \& Sridharan, R. (2002). The collaborative supply chain. International Journal of Logistics Management, 13, 15-30. http://dx.doi.org/10.1108/09574090210806333

Swartz, L. N. (1997). Exploring global franchising trends. Franchising world, 29(2).

Wrigley, N. ( 2000). The globalization of retail capital: Themes for economic geography. In G. L. Clark, M. P. Feldman, \& M. S. Gertler (Eds.), The Oxford Handbook of Economic Geography. Oxford, Oxford University Press.

Yavas, U., \& Secil, T. (1984). Perceived Risk in Grocery Outlet Selection: A Case Study in Saudi Arabia. European Journal of Marketing, 18(3). http://dx.doi.org/10.1108/09574090210806333

Young, J. (2001). Retailers opt for a market of eastern promise. Retail week.

\section{Copyrights}

Copyright for this article is retained by the author(s), with first publication rights granted to the journal.

This is an open-access article distributed under the terms and conditions of the Creative Commons Attribution license (http://creativecommons.org/licenses/by/3.0/). 